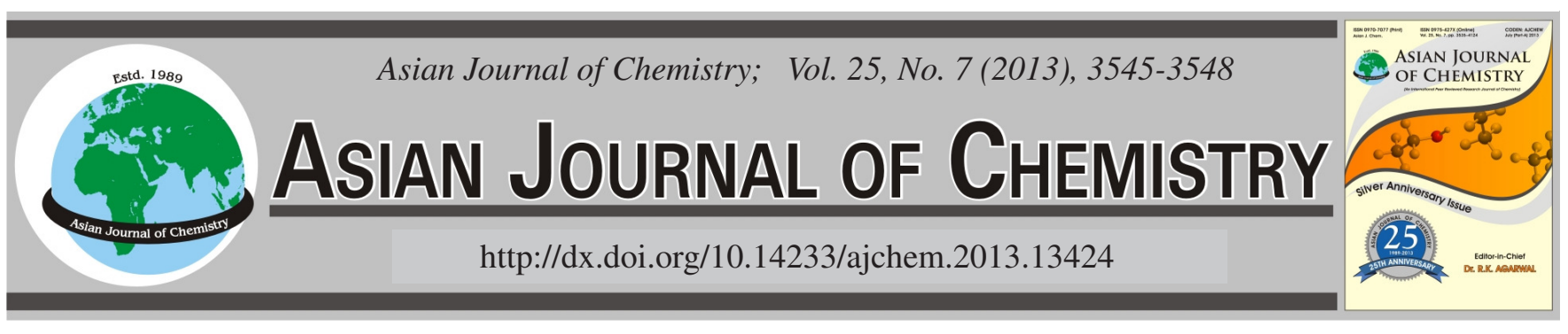

\title{
Effects of Liquid-to-Solid Ratio and Reaction Temperature on $\mathrm{NaOH}$ Pretreatment of Achnatherum splendens
}

\author{
L. TAO ${ }^{1,2}$ J. REN ${ }^{1,2, *}$, F.K. YU ${ }^{1,3}$ and T.R. NI ${ }^{1,3}$
}

${ }^{1}$ School of Environmental and Municipal Engineering, Institute of Environmental Ecology, Lanzhou Jiaotong University, Lanzhou 730070, P.R. China

${ }^{2}$ Engineering Research Center for Cold and Arid Regions Water Resource Comprehensive Utilization, Ministry of Education, Lanzhou 730070, P.R. China

${ }^{3}$ School of Environmental Science and Engineering, Nankai University, Tianjin 300100, P.R. China

*Corresponding author: E-mail: renjun@mail.lzjtu.cn

(Received: 11 January 2012;

Accepted: 4 January 2013)

AJC-12645

\begin{abstract}
In this study, the effects of several factors on $\mathrm{NaOH}$ pretreatment of Achnatherum splendens were investigated. It was found that $\mathrm{NaOH}$ loading, liquid-to-solid ratio and reaction temperature all had significant effects on delignification. These factors also had significant effects on the contents of lignin, hemicellulose and cellulose in the solids after $\mathrm{NaOH}$ pretreatment. The optimal pretreatment conditions were found to be $15 \%$ of $\mathrm{NaOH}$ loading, $10: 1$ of liquid-to-solid ratio, $90^{\circ} \mathrm{C}$ and $90 \mathrm{~min}$ of reaction time. Under the optimal conditions, approximate $39 \%$ of lignin was solubilized and the cellulose content was increased to $68.39 \%$ while the lignin and hemicellulose contents were decreased to $9.28 \%, 19.86 \%$, respectively. The lignin was effectively removed by $\mathrm{NaOH}$ pretreatment under mild conditions.

The results could be considered as a step towards the optimization of $\mathrm{NaOH}$ pretreatment of Achnatherum splendens.
\end{abstract}

Key Words: Liquid-to-solid ratio, Reaction temperature, NaoH pretreatment.

\section{INTRODUCTION}

Due to increasing energy consumption and environmental concerns, there has been increased interest in using ethanol as an alternative to fossil fuels ${ }^{1,2}$. It is not sustainable to produce ethanol from grains such as corn and wheat in China and some other countries. Lignocellulosic materials are attractive feedstock for ethanol production because they are abundant, cheap and renewable. However, in lignocellulosic materials, cellulose, a liner polymer of glucose is associated with hemicellulose and surrounded by lignin seal. Lignin, a complex three-dimensional polyaromatic matrix prevents enzymes from accessing some regions of the cellulose polymers. Crystallinity of the cellulose further impedes enzymatic hydrolysis ${ }^{3,4}$. Therefore, pretreatment has been studied as a key step for the effective utilization of lignocellulosic biomass feedstock ${ }^{5,6}$. The objective of lignocellulosic biomass pretreatment is to alter the structure of the lignocellulosic matrix to increase cellulose digestibility using cellulase enzymes ${ }^{7}$, which can be done by removing lignin, hemicelluloses, or a combination of the two. Lignin is a constituent that is known to inhibit saccharification enzymes and fermentative microorganisms ${ }^{8-10}$. Low-lignin substrates have improved microbial activity and enzyme efficiency, eventually lowering the enzyme requirement ${ }^{11}$.
Several processes have been developed for pretreatment of lignocellulosic biomass, including steam explosion ${ }^{12-15}$, liquid hot water pretreatment ${ }^{16}$, acid pretreatment ${ }^{17-21}$, alkali pretreatment $^{22-24}$, wet oxidation ${ }^{25,26}$ and peracetic acid pretreatment ${ }^{27,28}$. Alkali has been recognized as one of the most effective agents for delignification and swelling of the fibers. The main effect of sodium hydroxide pretreatment on lignocellulosic biomass is delignification by breaking the ester bonds cross-linking lignin and xylan, thus increasing the porosity of the biomass ${ }^{2,7,29}$. The main purpose of chemical pretreatment under mild condition $\left(<100{ }^{\circ} \mathrm{C}\right)$ is delignification and separating cellulose fibers ${ }^{24}$. In this paper, Achnatherum splendens was pretreated by $\mathrm{NaOH}$. Achnatherum splendens, which distributes widely in the north of China, is a tufty, perennial herbaceous plant of about $0.5-2.5 \mathrm{~m}$ in height. The plant grows rapidly and has a high tolerance for salt and drought. It is often found growing on infertile and poor land. Of special importance is the fact that the plant could be used for treatment of saline and alkali land and polluted soil. In this study, the factors that affect $\mathrm{NaOH}$ pretreatment of Achnatherum splendens were investigated. The factors of interest were $\mathrm{NaOH}$ loading, liquid-to-solid ratio and reaction temperature. 
TABLE-1

EFFECT OF NaOH LOADING ON THE COMPOSITIONS IN NaOH TREATED Achnatherum splendens. VALUES ARE MEANS OF TRIPLICATE MEASUREMENTS \pm STANDARD DEVIATION. VALUES WITH THE SAME LETTERS ARE NOT SIGNIFICANTLY DIFFERENT AMONG TREATMENTS AT $p<0.05$ ACCORDING TO TUKEY HSD TEST

\begin{tabular}{ccccc}
\hline $\mathrm{NaOH}$ loading (\%) & Lignin (\%) & Delignification $(\%)$ & Hemicellulose $(\%)$ & Cellulose $(\%)$ \\
\hline 3 & $12.29 \pm 0.06 \mathrm{a}$ & $1.54 \pm 0.46 \mathrm{a}$ & $30.80 \pm 0.39 \mathrm{a}$ & $55.86 \pm 0.42 \mathrm{a}$ \\
6 & $11.58 \pm 0.14 \mathrm{~b}$ & $5.66 \pm 1.15 \mathrm{a}$ & $23.61 \pm 0.89 \mathrm{~b}$ & $62.51 \pm 0.03 \mathrm{~b}$ \\
9 & $10.20 \pm 0.20 \mathrm{c}$ & $23.36 \pm 1.54 \mathrm{~b}$ & $23.25 \pm 0.11 \mathrm{~b}$ & $65.27 \pm 0.51 \mathrm{c}$ \\
12 & $10.17 \pm 0.43 \mathrm{c}$ & $28.29 \pm 3.05 \mathrm{c}$ & $19.92 \pm 0.59 \mathrm{c}$ & $66.11 \pm 0.58 \mathrm{c}$ \\
15 & $9.28 \pm 0.34 \mathrm{~d}$ & $38.86 \pm 2.21 \mathrm{~d}$ & $19.86 \pm 0.62 \mathrm{c}$ & $68.39 \pm 0.57 \mathrm{~d}$ \\
18 & $8.51 \pm 0.11 \mathrm{e}$ & $43.06 \pm 0.73 \mathrm{~d}$ & $18.66 \pm 0.85 \mathrm{c}$ & $69.15 \pm 0.52 \mathrm{~d}$ \\
\hline F-value & $98.82^{* * *}$ & $278.67 * * *$ & $147.24 * * *$ & $313.67 * * *$ \\
\hline
\end{tabular}

\section{EXPERIMENTAL}

Achnatherum splendens used in the study was obtained from Zhangye city in Gansu province of northwestern China. It was ground and screened to a nominal size of 20-60 mesh and then dried in oven at $105^{\circ} \mathrm{C}$ for $6 \mathrm{~h}$. The oven-dried samples were stored in valve bags at room temperature until use for pretreatment. Cellulose, hemicellulose and lignin were determined by the methods described by Goering and Vansoest ${ }^{30}$. The initial composition of the Achnatherum splendens was determined to be $45.31 \%$ cellulose, $31.46 \%$ hemicellulose, $9.59 \%$ lignin, $6.45 \%$ moisture content, $1.96 \%$ ash. Each sample was analyzed in duplicate. Statistical ANOVA analysis was determined by STATISTICA.

The pretreatment was carried out in a $1000 \mathrm{~mL}$ glass flask immersed in a water bath. The ground biomass was pretreated by $3-18 \%$ of $\mathrm{NaOH}$ loading (based on initial dry materials) with 8:1-20:1 (v/w) of liquid-to-solid ratio at $60-100{ }^{\circ} \mathrm{C}$ for 90 min. After $\mathrm{NaOH}$ pretreatment, the solids were washed with deionized water until neutrality and dried in oven at $105^{\circ} \mathrm{C}$ for $6 \mathrm{~h}$. The oven-dried samples were stored in valve bags at room temperature for further analysis.

\section{RESULTS AND DISCUSSION}

Effects of $\mathrm{NaOH}$ loading (based on initial dry materials): The effects of $\mathrm{NaOH}$ loading in $\mathrm{NaOH}$ pretreatment were investigated. The results are summarized in Table- 1 . The pretreatment conditions were $3-18 \%$ of $\mathrm{NaOH}$ loading (based on initial dry materials), $90{ }^{\circ} \mathrm{C}, 10: 1$ (v/w) of liquid-to-solid ratio and $90 \mathrm{~min}$ of reaction time. The yield of lignin and hemicellulose in solids pretreated by $\mathrm{NaOH}$ were decreased from $12.29 \%, 30.80 \%$ to $8.51 \%, 18.66 \%$, respectively when $\mathrm{NaOH}$ loading was increased from $3 \%$ to $18 \%$, but the yield of cellulose was increased from $55.86 \%$ to $69.15 \%$. Changes in $\mathrm{NaOH}$ loading caused significant decrease in lignin $(p<$ $0.001)$ and hemicellulose $(p<0.001)$ and significant increase in cellulose $(p<0.001)$. Treatment with $3 \%$ of $\mathrm{NaOH}$ loading achieved only $1.54 \%$ of delignification. It indicated that $3 \%$ $\mathrm{NaOH}$ is too low to affect delignification for treatment time up to $90 \mathrm{~min}$ and temperature up to $90^{\circ} \mathrm{C}$. When $\mathrm{NaOH}$ loading was increased to $18 \%$, the solubilization of lignin was increased to $43.06 \%$. An increase in $\mathrm{NaOH}$ loading significantly improved delignification $(p<0.001)$.

As compared with the treatment of $15 \%$ of $\mathrm{NaOH}$ loading, the lignin and cellulose contents of pretreated solids were significantly different at the treatments of 3, 6, 9 and $12 \%$ of $\mathrm{NaOH}$ loading. There was significant difference between the treatments of $15 \%$ and $18 \%$ of $\mathrm{NaOH}$ loading for the content of lignin in pretreated solids. However, for cellulose content of pretreated solids, there was no significant difference between the treatments of $15 \%$ and $18 \%$ of $\mathrm{NaOH}$ loading. The content of cellulose in pretreated solids was significantly different at the treatments of 3, 6 and $9 \%$ of $\mathrm{NaOH}$ loading as compared with the treatment of $15 \%$ of $\mathrm{NaOH}$ loading. However, for hemicellulose content of pretreated solids, there was no significant difference among the treatments of 12,15 and $18 \%$ of $\mathrm{NaOH}$ loading (Table-1).

As compared with the treatment of $15 \%$ of $\mathrm{NaOH}$ loading, delignification was significantly different at the treatments of 3, 6, 9 and $12 \%$ of $\mathrm{NaOH}$ loading. However, for delignification, there was no significant difference between the treatments of $15 \%$ and $18 \%$ of $\mathrm{NaOH}$ loading (Table- 1 ). It indicated that $\mathrm{NaOH}$ loading had no significant effects on delignification when higher than $15 \%$. Therefore, $15 \%$ of $\mathrm{NaOH}$ loading was selected for $\mathrm{NaOH}$ pretreatment.

Effect of liquid-to-solid ratio: In order to study the effects of liquid-to-solid ratio, five different liquid-to-solid ratios $(8: 1,10: 1,12: 1,15: 1$ and 20:1) were applied keeping the $\mathrm{NaOH}$ loading at $15 \%$ (based on initial dry materials), the reaction temperature at $90{ }^{\circ} \mathrm{C}$ and the reaction time for 90 min. The composition data after the treatment are summarized in Table-2. It was found that liquid-to-solid ratio had significant effects on yield of lignin $(p<0.05)$, hemicellulose $(p<$ $0.01)$ and cellulose $(p<0.05)$. The lignin and hemicellulose contents of the $\mathrm{NaOH}$ pretreated solids were decreased from $10.29 \%, 19.72 \%$ to $9.32 \%, 18.42 \%$, respectively when the liquid-to-solid ratio was increased from $8: 1$ to $10: 1$, but the cellulose content was increased from 66.94 to $68.34 \%$. The lignin and hemicellulose contents of solids pretreated by $\mathrm{NaOH}$ were increased to 9.76 and $19.78 \%$, respectively when the liquid-to-solid ratio was increased to $20: 1$, but the cellulose content was decreased to $66.78 \%$. Liquid-to-solid ratio had significant effects on delignification $(p<0.05)$. The delignification was increased from 31.70 to $38.71 \%$ when the liquid-to-solid ratio was increased from 8:1 to 10:1. But when the liquid-to-solid ratio was increased to $20: 1$, delignification was decreased to $32.85 \%$. It became hard to keep the reaction system homogeneous because of less liquid being present when liquid-to-solid ratio was lower than 10:1. When $\mathrm{NaOH}$ loading was fixed, higher liquid-to-solid ratio led to lower $\mathrm{NaOH}$ concentration in the liquid phase, which further decreased the delignification.

For lignin, hemicellulose and cellulose contents of pretreated solids, there was significant difference between the 
TABLE-2

EFFECT OF LIQUID-TO-SOLID RATIO ON THE COMPOSITIONS IN NaOH TREATED Achnatherum splendens. VALUES ARE MEANS OF TRIPLICATE MEASUREMENTS \pm STANDARD DEVIATION. VALUES WITH THE SAME LETTERS ARE NOT SIGNIFICANTLY DIFFERENT AMONG TREATMENTS AT $\mathrm{p}<0.05$ ACCORDING TO TUKEY HSD TEST

\begin{tabular}{ccccc}
\hline Liquid-to-solid ratio (v/w) & Lignin $(\%)$ & Delignification $(\%)$ & Hemicellulose (\%) & Cellulose (\%) \\
\hline $8: 1$ & $10.29 \pm 0.35 \mathrm{a}$ & $31.70 \pm 2.33 \mathrm{a}$ & $19.72 \pm 0.16 \mathrm{a}$ & $66.94 \pm 0.20 \mathrm{a}$ \\
$10: 1$ & $9.32 \pm 0.26 \mathrm{~b}$ & $38.71 \pm 1.71 \mathrm{~b}$ & $18.42 \pm 0.31 \mathrm{~b}$ & $68.34 \pm 0.46 \mathrm{~b}$ \\
$12: 1$ & $9.61 \pm 0.39 \mathrm{ab}$ & $34.99 \pm 2.65 \mathrm{ab}$ & $18.50 \pm 0.10 \mathrm{~b}$ & $67.62 \pm 0.38 \mathrm{ab}$ \\
$15: 1$ & $9.63 \pm 0.29 \mathrm{ab}$ & $34.96 \pm 1.93 \mathrm{ab}$ & $18.55 \pm 0.39 \mathrm{~b}$ & $67.48 \pm 0.10 \mathrm{ab}$ \\
$20: 1$ & $9.76 \pm 0.31 \mathrm{ab}$ & $32.85 \pm 2.15 \mathrm{a}$ & $19.78 \pm 0.44 \mathrm{a}$ & $66.78 \pm 0.52 \mathrm{a}$ \\
\hline F-value & $3.65^{*}$ & $4.52^{*}$ & $15.08^{* *}$ & $6.23^{*}$ \\
\hline
\end{tabular}

TABLE-3

EFFECT OF REACTION TEMPERATURE ON THE COMPOSITIONS IN NaOH TREATED Achnatherum splendens. VALUES ARE MEANS OF TRIPLICATE MEASUREMENTS \pm STANDARD DEVIATION. VALUES WITH THE SAME LETTERS ARE NOT SIGNIFICANTLY DIFFERENT AMONG TREATMENTS AT $\mathrm{p}<0.05$ ACCORDING TO TUKEY HSD TEST

\begin{tabular}{ccccc}
\hline Temperatures $\left({ }^{\circ} \mathrm{C}\right)$ & Lignin $(\%)$ & Delignification $(\%)$ & Hemicellulose $(\%)$ & Cellulose $(\%)$ \\
\hline 60 & $11.62 \pm 0.14 \mathrm{a}$ & $8.3 \pm 1.07 \mathrm{a}$ & $23.13 \pm 0.43 \mathrm{a}$ & $63.46 \pm 0.24 \mathrm{a}$ \\
70 & $11.24 \pm 0.49 \mathrm{ab}$ & $13.09 \pm 3.77 \mathrm{a}$ & $21.84 \pm 0.92 \mathrm{ab}$ & $63.49 \pm 0.47 \mathrm{a}$ \\
80 & $10.52 \pm 0.36 \mathrm{bc}$ & $25.39 \pm 2.55 \mathrm{~b}$ & $21.63 \pm 0.41 \mathrm{bc}$ & $64.83 \pm 0.29 \mathrm{~b}$ \\
90 & $9.68 \pm 0.45 \mathrm{c}$ & $31.55 \pm 3.15 \mathrm{bc}$ & $18.97 \pm 0.31 \mathrm{~d}$ & $66.53 \pm 0.54 \mathrm{c}$ \\
100 & $9.58 \pm 0.29 \mathrm{c}$ & $34.48 \pm 1.98 \mathrm{c}$ & $18.65 \pm 0.26 \mathrm{~d}$ & $67.69 \pm 0.14 \mathrm{~d}$ \\
\hline F-value & $18.53^{* *}$ & $54.91^{* * *}$ & $41.65^{* * *}$ & $78.39^{* * *}$ \\
\hline
\end{tabular}

treatments of 8:1 and 10:1 of liquid-to-solid ratio. However, there was no significant difference among the treatments of 10:1, 12:1, 15:1 and 20:1 of liquid-to-solid ratio for lignin content of pretreated solids. There was no significant difference among the treatments of 10:1, 12:1 and 15:1 of liquid-to-solid ratio for the contents of hemicellulose and cellulose in pretreated solids. However, for hemicellulose and cellulose contents of pretreated solids, there was significant difference between the treatments of 10:1 and 20:1 of liquid-to-solid ratio (Table-2).

As compared with the treatment of 8:1 of liquid-to-solid ratio, delignification was significantly different at the treatment of 10:1 of liquid-to-solid ratio. However, there was no significant difference among the treatments of 10:1, 12:1 and 15:1 of liquid-to-solid ratio for delignification. There was significant difference between the treatments of 10:1 and 20:1 of liquid-to-solid ratio for delignification. Treatment at 10:1 of liquid-to-solid ratio achieved $38.71 \%$ of delignification which was the maximum delignification (Table-2). Therefore, 10:1 was the liquid-to-solid ratio selected for $\mathrm{NaOH}$ pretreatment.

Effect of reaction temperature: Table- 3 summarizes the changes of composition with reaction temperature. The pretreatment conditions were $60-100{ }^{\circ} \mathrm{C}, 12 \%$ of $\mathrm{NaOH}$ loading (based on initial dry materials), 8:1 (v/w) of liquid-to-solid ratio and $90 \mathrm{~min}$ of reaction time. The amount of lignin and hemicellulose in solids after $\mathrm{NaOH}$ pretreatment were decreased from $11.62 \%, 23.13 \%$ to $9.58 \%, 18.65 \%$, respectively when reaction temperature was increased from 60 to $100{ }^{\circ} \mathrm{C}$, but the amount of cellulose was increased from 63.46 to $67.69 \%$. Increasing of reaction temperature resulted in significant decrease in lignin $(p<0.01)$ and hemicellulose $(p$ $<0.001)$ and significant increase in cellulose $(p<0.001)$. Delignification was in the range of 8.3-34.48 \% with 60-100 ${ }^{\circ} \mathrm{C}$ of reaction temperature. The reaction temperature had significant effects on delignification $(p<0.001)$. Treatment at $60{ }^{\circ} \mathrm{C}$ achieved $8.3 \%$ of delignification. It indicated that 60 ${ }^{\circ} \mathrm{C}$ is too low to affect delignification. However, only $34.48 \%$ of lignin was dissolved when the temperature was increased to $100{ }^{\circ} \mathrm{C}$. Perhaps using higher temperatures could further remove lignin.

As compared with the treatment of $90^{\circ} \mathrm{C}$, the content of lignin in pretreated solids was significantly different at the treatments of $60^{\circ} \mathrm{C}$ and $70{ }^{\circ} \mathrm{C}$. However, there was no significant difference among the treatments of 80,90 and $100{ }^{\circ} \mathrm{C}$ for the content of lignin in pretreated solids. As compared with the treatment of $90{ }^{\circ} \mathrm{C}$, hemicellulose and cellulose contents of pretreated solids were significantly different at the treatments of 60,70 and $80{ }^{\circ} \mathrm{C}$. There was no significant difference between the treatments of $90^{\circ} \mathrm{C}$ and $100^{\circ} \mathrm{C}$ for hemicellulose contents of pretreated solids. However, there was significant difference between the treatments of $90{ }^{\circ} \mathrm{C}$ and $100{ }^{\circ} \mathrm{C}$ for the content of cellulose in pretreated solids (Table-3).

As compared with the treatment of $90^{\circ} \mathrm{C}$, delignification was significantly different at the treatments of 60 and $70{ }^{\circ} \mathrm{C}$. However, there was no significant difference between the treatments of $80^{\circ} \mathrm{C}$ and $90^{\circ} \mathrm{C}$ for delignification. Similarly, there was no significant difference between the treatments of 90 and $100{ }^{\circ} \mathrm{C}$ for delignification. However, there was significant difference between the treatments of 80 and $100^{\circ} \mathrm{C}$ for delignification (Table-3). It indicated that reaction temperature had no significant effects on delignification when over $90{ }^{\circ} \mathrm{C}$. Therefore, $90^{\circ} \mathrm{C}$ was selected for $\mathrm{NaOH}$ pretreatment.

On the basis of the collective experimental data of delignification was determined to the optimum operating condition of the $\mathrm{NaOH}$ pretreatment to be: $15 \%$ of $\mathrm{NaOH}$ loading, 10:1 of liquid-to-solid ratio, $90{ }^{\circ} \mathrm{C}$ and $90 \mathrm{~min}$ of reaction time. Under the optimal condition, approximately $39 \%$ lignin was removed. Silverstein et $a l .{ }^{24}$ reported $65.63 \%$ delignification as a result of pretreatment of cotton stalks with $2 \% \mathrm{NaOH}$ for $90 \mathrm{~min}$ at $121{ }^{\circ} \mathrm{C} / 15 \mathrm{psi}$ in the autoclave. The higher delignification level may be attributed to two reasons. One reason may be a higher reaction temperature of $121^{\circ} \mathrm{C}$, which in this study was limited to $100{ }^{\circ} \mathrm{C}$ and another reason may be related to the nature of Achnatherum splenden. 


\section{Conclusion}

The lignin was effectively removed by $\mathrm{NaOH}$ pretreatment under mild conditions. It was showed that $\mathrm{NaOH}$ loading, liquidto-solid ratio and reaction temperature all had significant effects on delignification. These factors also had signiifcant effects on the content of lignin, hemicellulose and cellulose in the solids after $\mathrm{NaOH}$ pretreatment. The optimum treatment conditions of $\mathrm{NaOH}$ pretreatment for Achnatherum splendens were found to be $15 \%$ of $\mathrm{NaOH}$ loading (based on initial dry materials), 10:1 (v/w) of liquid-to-solid ratio, $90{ }^{\circ} \mathrm{C}$ and $90 \mathrm{~min}$ of reaction time. Under these conditions, approximate $39 \%$ of lignin was solubilized and the content of cellulose was increased to $68.39 \%$ while the content of hemicellulose was decreased to $19.86 \%$. In addition, this study can serve as a step towards the optimization of $\mathrm{NaOH}$ pretreatment of Achnatherum splendens. Nevertheless, perhaps application of higher temperatures and pressures could be investigated. In addition, enzymatic hydrolysis using optimized pretreatment factors and ethanol fermentation need to be studied for bioethanol production since they could not be addressed in this study.

\section{ACKNOWLEDGEMENTS}

This research was supported by Program for Changjiang Scholars and Innovative Research Team in University (IRT0966) and by the National Natural Science Foundation (No. 30970490).

\section{REFERENCES}

1. J.W. Lee, R.C.L.B. Rodrigues, H.J. Kim, I.G. Choi and T.W. Jeffries, Bioresour. Technol., 101, 4379 (2010).

2. R.A. Silverstein, Y. Chen, R.R. Sharma-Shivappa, M. Boyette and J.A Osborne, Bioresour. Technol., 98, 3000 (2007).

3. Z. Xu, Q.H. Wang, Z.H. Jiang, X.X. Yang and Y.Z. Ji, Biomass Bioenergy, 31, 162 (2007)

4. R.J. Bothast and B.C. Saha, Adv. Appl. Microbiol., 44, 261 (1997).

5. T.H. Kim, F. Taylor and K.B. Hicks, Bioresour. Technol., 99, 5694 (2008).
6. X.B. Zhao, L.H. Zhang and D.H. Liu, Bioresour. Technol., 99, 3729 (2008).

7. N. Mosier, C. Wyman, B. Dale, R. Elander, Y.Y. Lee and M. Holtzapple, Bioresour. Technol., 96, 673 (2005).

8. V.S. Chang and M.T. Holtzapple, Appl. Biochem. Biotechnol., 84-86, 5 (2000).

9. C.A. Mooney, S.D. Mansfield, M.G. Touhy and J.N. Saddler, Bioresour. Technol., 64, 113 (1998).

10. M.J. Selig, S. Viamajala, S.R. Decker, M.P. Tucker, M.E. Himmel and T.B. Vinzant, Biotechnol. Progr., 23, 1333 (2007).

11. T.H. Kim, J.S. Kim, C. Sunwoo and Y.Y. Lee, Bioresour. Technol., 90, 39 (2003).

12. C. Martin, M. Galbe, N.O. Nilvebrant and L.J. Jonsson, Appl. Biochem. Biotechnol., 98, 699 (2002).

13. B. Palmarola-Adrados, M. Galbe and G. Zacchi, J. Chem. Technol. Biotechnol., 80, 85 (2005).

14. K. Ohgren, R. Bura, J. Saddler and G. Zacchi, Bioresour. Technol., 98, 2503 (2007).

15. X.B. Zhao, L. Wang and D.H. Liu, J. Chem. Technol. Biotechnol., 83, 950 (2008)

16. J.A. Perez, A. Gonzalez, J.M. Oliva, I. Ballesteros and P. Manzanares, J. Chem. Technol. Biotechnol., 82, 929 (2007).

17. S.S. Silva, Z.R. Matos and W. Carvalho, Biotechnol. Progr., 21, 1449 (2005).

18. Y. Sun and J.J. Cheng, Bioresour. Technol., 96, 1599 (2005)

19. L.S. Yan, H.M. Zhang, J.W. Chen, Z.X. Lin, Q. Jin and H.H. Jia, Bioresour. Technol., 100, 1803 (2009).

20. T.A. Lloyd and C.E. Wyman, Bioresour. Technol., 96, 1967 (2005).

21. G.L. Guo, W.H. Chen, L.C. Men and W.S. Hwang, Bioresour. Technol., 99, 6046 (2008).

22. T.H. Kim and Y.Y. Lee, Appl. Biochem. Biotechnol., 124, 1119 (2005).

23. R. Jun, T. Ling, N. Tianri, H. Jianxiu and G. Yamei, Asian J. Chem., 23, 4407 (2011).

24. X.B. Zhao, F. Peng, K.K. Cheng and D.H. Liu, Enzyme Microb. Technol., 44, 17 (2009).

25. C. Martín, H.B. Klinke and A.B. Thomsen, Enzyme Microb. Technol., 40, 426 (2007).

26. C. Martin and A.B. Thomsen, J. Chem. Technol. Biotechnol., 82, 174 (2007).

27. X.B. Zhao, L. Wang and D.H. Liu, J. Chem. Technol. Biotechnol., 82, 1115 (2007).

28. L.C. Teixeira, J.C. Linden and H.A. Schroeder, Renewable Energy, 77-79, 19 (1999).

29. Y. Sun and J. Cheng, Bioresour. Technol., 83, 1 (2002).

30. H.K. Goering and P.J. Vansoest, Agriculture handbook, Agricultural Research Services, United States Department of Agriculture, No. 379 (1970). 